\title{
Pengembangan Digital Dictionary untuk Mengukur Retensi Mahasiswa Pendidikan Guru Madrasah Ibtidaiyah (PGMI)
}

\author{
Vannisa Aviana Melinda, Dian Eka Aprilia Fitria Ningrum \\ Universitas Islam Negeri Maulana Malik Ibrahim Malang
}

\section{Edcomtech}

Jurnal Kajian

Teknologi Pendidikan

Volume 5, No 2, Oktober 2020

145-154

Submitted 17-11-2019

Accepted 23-06-2019

Corresponding Author

Vannisa Aviana Melinda

vannisamelinda19@uin-malang.ac.id

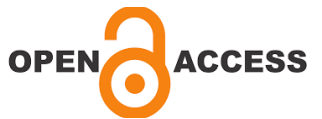

\begin{abstract}
Abstrak
Tujuan penelitian ini adalah untuk menghasilkan digital dictionary dan mengetahui peningkatan retensi mahasiswa dengan menggunakan digital dictionary. Penelitian ini merupakan $R \& D$ dengan menggunakan model pengembangan media pembelajaran oleh Lee dan Owens, dikarenakan dalam model pengembangan ini memiliki alur lengkap seperti tahap analisis dan penilaian, tahap desain, tahap pengembangan, tahap implementasi, dan tahap evaluasi. Keseluruhan hasil validasi ahli materi terhadap media digital dictionary yang dikembangkan yaitu 92,30\% dengan kategori valid. Hasil validasi ahli media terhadap media digital dictionary yang dikembangkan yaitu $91,67 \%$ dengan kategori valid. Pada penelitian ini, variabel terikat yang digunakan adalah daya retensi (retention rate) siswa terhadap istilah-istilah biologi yang terkandung dalam materi pokok tumbuhan, hewan dan manusia. Pada penelitian ini diperoleh data rerata retensi mahasiswa dalam kurun waktu 2 minggu masih tergolong B (baik) dengan skor 78,46. Sehingga, media digital dictionary dapat meningkatkan daya retensi mahasiswa.
\end{abstract}

Kata kunci: $R \& D$, Digital dictionary, dan Retensi.

\begin{abstract}
The purpose of this research is to produce a digital dictionary and to know the increase in student retention by using digital dictionary. The research is an R\&D using a learning Media development model by Lee and Owens, because in this development model has complete flows such as analysis and assessment stages, design stage, development stage, implementation phase, and evaluation phase. The overall validation result of material experts on the digital Media dictionary developed is $92.30 \%$ with valid categories. Media expert validation result of the developed digital media dictionary which is $91.67 \%$ with valid category. In this study, the bonded variables used were the power of the retention (retention rate) of students against the biological terms contained in the subject matter of plants, animals and humans. In this study, data on student retention rate in 2 weeks was still classified as $B$ (good) with a score of 78.46. Thus, digital media dictionary can increase the ability of student's retention.
\end{abstract}

Keywords: R\&D, Digital dictionary, dan Retensi. 


\section{PENDAHULUAN}

Era transformasi pendidikan abad 21 merupakan arus perubahan di mana seorang pendidik dan peserta didik akan samasama berperan penting dalam keberhasilan pembelajaran. Memasuki abad ke-21 yang mana dikenal dengan abad pengetahuan yang akan menjadi landasan utama dalam segala aspek kehidupan. (Trilling dan Hood, 1999). Abad pengetahuan merupakan suatu era dengan spesifikasi tertentu yang besar pengaruhnya terhadap dunia pendidikan dan juga pada lapangan kerja.

Seorang pendidik tidak hanya menguasai pengetahuan akademik, pedagogik dan sosial, namun juga harus mampu menguasai IT baik untuk mempersiapkan perencanaan pembelajaran maupun untuk menerapkan berbagai model pembelajaran berbasis teknologi dalam kegiatan pembelajaran seperti penggunaan multimedia interaktif atau, e-learning, mobile learning, blended learning ataupun pembelajaran berbasis elektronik lainnya (Rusman, 2017).

Manajemen pendidikan modern salah satunya adalah penggunaan prinsipprinsip belajar berorientasi pada teknologi, misalnya penggunaan mobile learning dalam pembelajaran. Menurut Ningsih (2019), Penggunaan mobile learning merupakan sebuah alternatif untuk memecahkan permasalahan pembelajaran, selain itu karakteristik kepraktisan mobile learning yang dapat dibawa kemanapun menjadi salah satu daya tarik bagi pengguna agar memudahkan pembelajaran.

Dalam penggunaan mobile learning pun banyak jenisnya, Adapun seperti menggunakan media berupa kamus dalam bentuk digital atau digital dictionary. Digital dictionary atau kamus digital ialah suatu cara untuk mengembangkan sebuah media pembelajaran dengan menggunakan teknologi terkini. Karena metode pembelajaran menggunakan kamus cetak dapat dipandang kurang efektif, tidak praktis dan pencarian kosa kata yang masih manual dengan satu-persatu arti kosa kata dan hal ini dapat menyita waktu.
Digital dictionary yang dikembangkan lebih mengarah pada mobile learning, dilihat dari banyaknya pengguna yang lebih merasa praktis karena dapat digunakan langsung pada handphone, namun digital dictionary juga dapat digunakan pada komputer. Mengacu pada penelitian yang dilakukan oleh Sambung (2017) menunjukkan bahwa penggunaan aplikasi mobile learning dinyatakan sangat valid dan dapat digunakan sebagai aplikasi mobile learning dalam pembelajaran kosakata bahasa Jepang. Hal tersebut dibuktikan dengan hasil perhitungan statistik yaitu sebesar $100 \%$ yang diperoleh dari ahli media, sedangkan ahli materi sebesar $86 \%$, skor persentase sebesar $92,5 \%$ dari uji coba perseorangan, skor persentase $89 \%$ dari uji coba kelompok kecil dan dari uji lapangan didapat skor persentase $87 \%$.

Era informasi saat ini menyebabkan status kamus berubah, dan begitu pula pola perilaku pengguna yang lebih memanfaatkan internet untuk mencari makna suatu hal, padahal terdapat beberapa sumber di internet yang melanggar leksikografis. Jelas, kita perlu tahu lebih banyak tentang perilaku pengguna di lingkungan digital khususnya mahasiswa, dan untuk ini kita perlu memanfaatkan penelitian pengguna, untuk mengetahui bagaimana alat referensi leksikal yang semakin fleksibel dan adaptif di masa depan untuk mengakomodasi kebutuhan pengguna dengan sebaik-baiknya. Tantangan untuk menghasilkan kamus yang efisien dan efektif paling baik dilihat dalam konteks keterampilan referensi pengguna kamus, yang sekarang cenderung tumpang tindih dengan literasi digital.

Diketahui secara umum bahwa penggunaan teknologi terkini dapat memberikan pengaruh atau dampak yang positif dalam proses pembelajaran, khususnya dalam hal mengingat materi yang telah diajarkan kepada mahasiswa dalam hal dalam jangka waktu yang panjang yang biasa disebut sebagai daya retensi.

Retensi dapat menunjukkan bahwa apa yang dipelajari tidak menghasilkan efek praktis kecuali dengan mengingat cukup lama. Proses pembelajaran akan berjalan dengan 
lancar jika peserta didik memiliki retensi baik, namun ketika peserta didik memiliki retensi rendah maka akan timbul masalah karena proses pembelajaran akan lambat dan tujuan pembelajaran tidak tercapai (Rahman, 2010). Sedangkan menurut Juniarsih et al, (2015) Faktor retensi atau lekatnya konsep dalam ingatan kurang mendapat perhatian padahal hal ini dapat dijadikan sebagai indikator bermutunya hasil belajar atau pembelajaran. Untuk itu pentingya penggunaan media pembelajaran yang tepat dapat digunakan oleh pendidik agar peserta didik memiliki retensi yang baik atau peningkatan retensi dalam materi pembelajaran, yang mana pada akhirnya retensi yang baik akan menjadikan keberhasilan pembelajaran.

\section{METODE}

\section{Model Pengembangan}

Penelitian ini merupakan Research and Development (R\&D), dengan model pengembangan milik Lee dan Owens (2004). Peneliti menggunakan model pengembangan media pembelajaran Lee dan Owens karena dalam model pengembangan ini memiliki alur lengkap seperti tahap analisis, tahap desain, tahap pengembangan, tahap implementasi, dan tahap evaluasi.

Pada tahap analisis dibagi kedalam dua tahapan, tahapan pertama adalah analisis kebutuhan yaitu sebuah tahapan yang sistematis untuk menentukan kesenjangan antara keadaan yang sebenarnya dengan keadaan yang diinginkan, tahapan kedua adalah analisis awal dan akhir merupakan sebuah teknik pengumpulan data yang dapat digunakan untuk menjembatani antara kesenjangan dengan menentukan solusi apa yang akan diperlukan. Tahap kedua yaitu desain adalah tahapan merencanakan sebuah media digital dictionary, perencanaan adalah bagian yang sangat penting untuk meraih kesuksesan dalam mengembangkan digital dictionary. Tahapan ketiga yaitu tahapan mengembangkan, yang mana proses ini dilakukan untuk mengembangkan elemenelemen media pada yang sebelumnya sudah disusun melalui kerangka media digital dictionary.
Setelah melalui proses pengembangan elemen-elemen media digital dictionary, tahap selanjutnya adalah riviu produk. Tahap pertama adalah menjalankan aplikasi kosakata, apakah aplikasi ini dapat berjalan dengan baik dan sesuai keinginan pengembang, tahap kedua yaitu melakukan uji coba media oleh ahli media dan ahli materi, tahap ini dilakukan untuk mencari kekurangan dan adanya kesalahan dari produk media tersebut, jika dinyatakan masih ada kekurangan dari produk tersebut, hal yang harus dilakukan adalah merevisi produk. Selanjutnya adalah tahapan untuk implementasi media digital dictionary, pada tahap ini media digital dictionary sudah dinyatakan siap untuk digunakan dan akan direvisi kembali pada tahapan terakhir yaitu evaluasi, yang mana jika masih ditemukan kekurangan pada media digital dictionary.

\section{Teknik Analisis Data}

Teknik analisis data dilakukan agar memperoleh pemahaman yang konkret tentang keberhasilan dari Digital dictionary yang telah diproduksi. Teknik analisis dan interpretasi data yang digunakan berupa skor angket. Hasil yang diperoleh digunakan untuk pertimbangan dalam memperbaiki produk dari pengembangan.

Skor angket yang berupa penilaian yang diberikan kepada ahli materi, ahli media dan mahasiswa. Data yang dihasilkan berupa deskripsi kualitatif, namun sebelum dideskripsikan data harus dianalisis terlebih dahulu dengan rumus perhitungan (Arikunto, 2010:236):

$$
P=\frac{\text { Juml ah ksseluruhan jawaban respondan }}{\text { Jumlah sk or maksimal seluruh itam }} \times 100 \%
$$

Keterangan :

$\mathrm{P}=$ Persentase

$100=$ Konstanta

Pedoman yang digunakan untuk menilai kelayakan terbagi menjadi beberapa yang akan dijabarkan pada kriteria kevalidan media pembelajaran sebagai berikut: 
Tabel 1. Adaptasi Kriteria Tingkat Kelayakan Kategori Persentase Skor Keterangan (\%)

\begin{tabular}{cccl}
\hline A & $76-100$ & 4 & Valid \\
B & $51-75$ & 3 & Cukup Valid \\
C & $26-50$ & 2 & Kurang Valid \\
D & $0-25$ & 1 & Tidak Valid \\
\hline
\end{tabular}

(Arikunto,2010)

Retensi belajar mahasiswa ditentukan menggunakan skala absolut dengan 5 kategori: A, B, C, D dan E. Kategori A (sangat baik) untuk skor 80-100, kategori B (baik) untuk skor 60-79, kategori $C$ (sedang) untuk skor 40-59, kategori D (kurang) untuk skor 2039 dan kategori E (sangat kurang) untuk skor >20 (Gronlund \& Linn, 1990).

\section{HASIL dan PEMBAHASAN}

Pada bagian pertama akan diuraikan hasil validasi yang diperoleh dari ahli materi dan ahli media yang dirangkum pada Tabel 2 berikut.

Tabel 2. Hasil Validasi Ahli

\begin{tabular}{lcc}
\hline Validasi Ahli & Skor & Keterangan \\
\hline Ahli materi/isi & 92.30 & Valid \\
Ahli media & 91.67 & Valid \\
\hline
\end{tabular}

Pada bagian kedua akan diuraikan hasil pengukuran retensi mahasiswa. Pengukuran retensi mahasiswa sama seperti pengukuran hasil belajar yaitu menggunakan instrument tes. Tes awal (pretest) dilakukan untuk mengetahui kemampuan awal mahasiswa sebelum menggunakan digital dictionary. Nilai retensi (posttest) diambil setelah 2 minggu pengambilan data pretest. Rerata nilai retensi siswa tersaji pada Tabel 3 berikut.

Tabel 3. Nilai Mahasiswa

\begin{tabular}{cccccc}
\hline Mahasiswa & Pretest & 1 & 2 & 3 & Posttest \\
\hline 1 & 40 & 76 & 91 & 80 & 82 \\
2 & 20 & 72 & 78 & 76 & 76 \\
3 & 40 & 70 & 78 & 74 & 74 \\
4 & 27 & 64 & 78 & 76 & 73 \\
5 & 40 & 76 & 91 & 92 & 86 \\
6 & 27 & 74 & 74 & 92 & 80 \\
7 & 60 & 76 & 91 & 88 & 85 \\
8 & 20 & 76 & 84 & 76 & 79 \\
9 & 40 & 74 & 91 & 88 & 84 \\
10 & 40 & 72 & 84 & 88 & 81 \\
11 & 47 & 64 & 78 & 76 & 73 \\
12 & 47 & 72 & 88 & 92 & 84 \\
13 & 40 & 76 & 84 & 88 & 83 \\
14 & 40 & 70 & 74 & 76 & 73 \\
15 & 47 & 64 & 91 & 74 & 76 \\
16 & 40 & 64 & 84 & 92 & 80 \\
17 & 60 & 58 & 84 & 80 & 74 \\
18 & 40 & 58 & 84 & 80 & 74 \\
19 & 53 & 70 & 84 & 80 & 78 \\
20 & 7 & 58 & 84 & 80 & 74 \\
21 & 80 & 72 & 88 & 92 & 84 \\
22 & 53 & 64 & 88 & 80 & 77 \\
23 & 40 & 70 & 84 & 80 & 78 \\
24 & 47 & 58 & 88 & 80 & 75 \\
\hline Rata-rata & 41.46 & 68.67 & 84.29 & 82.5 & 78.46 \\
\hline & & & & &
\end{tabular}




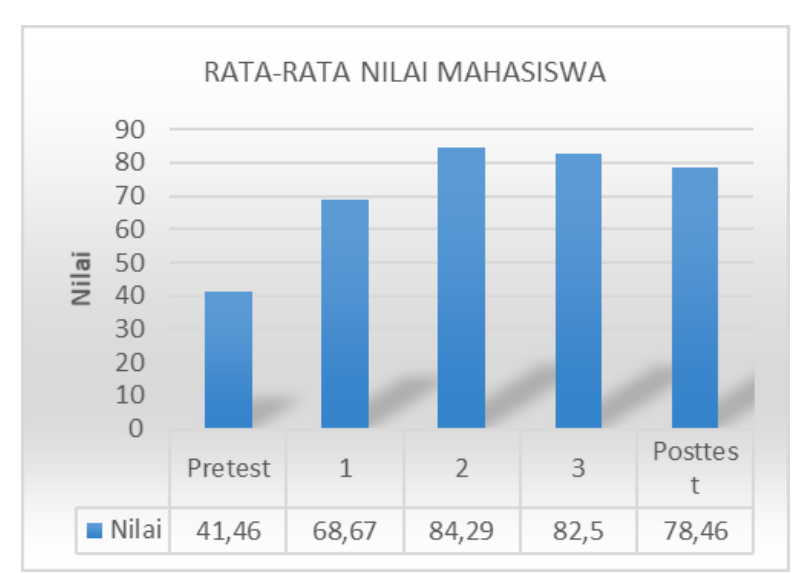

Gambar 1. Grafik Rata-rata Nilai Mahasiswa

Berdasarkan gambar tersebut, maka rerata retensi mahasiswa tergolong $B$ (baik) dengan skor 78,46.

\section{Pembahasan}

Digital dictionary atau kamus elektronik merupakan kamus yang dikemas dalam bentuk elektronik yang dapat didistribusikan secara daring (online) maupun offline melalui jaringan komputer, internet, atau handpone. Sebelum membahas tentang digital dictionary penulis akan membahas pentingnya kamus dalam menguasai kosa kata atau kata-kata ilmiah yang tidak mudah untuk dihafalkan dengan cepat. Selain itu, kosa kata dan katakata ilmiah juga tidak mudah diingat dalam jangka waktu yang lama, maka dari itu butuh kamus untuk mempermudah proses membaca, menghafalkan dan mengingat. Kamus yang digunakan dapat terdiri dari kamus online, kamus offline, kamus cetak, kamus elektronik atau digital dictionary. Penelitian Laufer dan Hill (2000) menunjukkan bahwa setelah menggunakan kamus online selama tugas membaca, pelajar Hongkong dapat mengingat $62 \%$ dari kata-kata.

Hurman dan Tall (1998) menyatakan dalam rekomendasinya bahwa "Pelatihan dalam penggunaan kamus harus dimulai sejak awal dalam pembelajaran bahasa modern dan harus menjadi bagian integral dari pembelajaran siswa." Bishop (2000) menyimpulkan bahwa ada potensi untuk pelatihan yang lebih baik dalam penggunaan kamus untuk memperluas jangkauan penggunaan yang dibuat untuk para peserta didik, baik di seluruh proses pembelajaran dan dalam kondisi ujian, namun pelatihan seperti itu mungkin tidak mudah untuk dirancang. Dari penelitianpenelitian terdahulu, maka dapat dijadikan pelajaran agar menjadikan kamus lebih praktis dan mudah dipahami oleh pengguna, dengan melihat kondisi saat ini masyarakat telah banyak menggunakan komputer dan handphone maka sudah saatnya kamus di desain canggih dan menarik yang bersifat online atau offline yang dapat diakses melalui komputer atau handphone. .

Pada era digital saat ini handphone dijadikan sebagai perangkat bergerak telah menjadi teknologi persavive yang berpengaruh pada setiap sendi kehidupan manusia sehingga dapat memunculkan beberapa istilah baru dalam masyarakat digital, diantaranya "society on the move" yang mana istilah ini muncul dikarenakan semakin berkembangnya fungsi dari handphone yang saat ini bukan lagi hanya berfungsi sebagai alat komunikasi saja tetapi dapat dijadikan perangkat yang multifungsi yang kaya akan fitur (Ulfa, 2014).

Digital dictionary merupakan kamus yang datanya dalam bentuk digital yang dapat diakses melalui sejumlah media yang berbeda (Nesi, 2009: 458-478). Dengan berkembangnya teknologi dan zaman Digital dictionary yang digunakan dalam proses pembelajaran hasilnya pastinya lebih efektif, karena sifatnya yang efisien dan dapat dibawa kemanapun atau mobile.

Kamus dengan bentuk digital merupakan perkembangan terbaru di bidang leksiokrafi. Kamus digital menawarkan beberapa kelebihan yaitu, informasi yang diberikan lebih banyak dari kamus konvesional, kamus ini dapat diisikan multimedia seperti gambar, suara atau animasi, dan pencarian kata yang diinginkan akan lebih cepat daripada kamus konvensional. Kamus digital juga menawarkan definisi dan contoh yang diambil dari sumber rujukan buku cetak. Kamus digital juga menawarkan karakteristik yang tidak ada dalam kamus konvensional. Fitur yang biasa ada dalam ialah fitur pengucapan dan fitur hyperlink dari kata ke kata lain yang berfungsi memperjelas makna kata yang terkait (Tribble, 2003: 194).

Digital dictionary (Gambar 2) yang 
dikembangkan dikemas dalam aplikasi dan dapat diinstal pada android yang dimiliki mahasiswa. Pemilihan media kamus digital digunakan karena dalam materi IPA terdapat istilah-istilah asing yang menyulitkan mahasiswa dalam memahami konten materi. Pengembangan media digital dictionary menggunakan model pengembangan Lee dan Owens (2004).
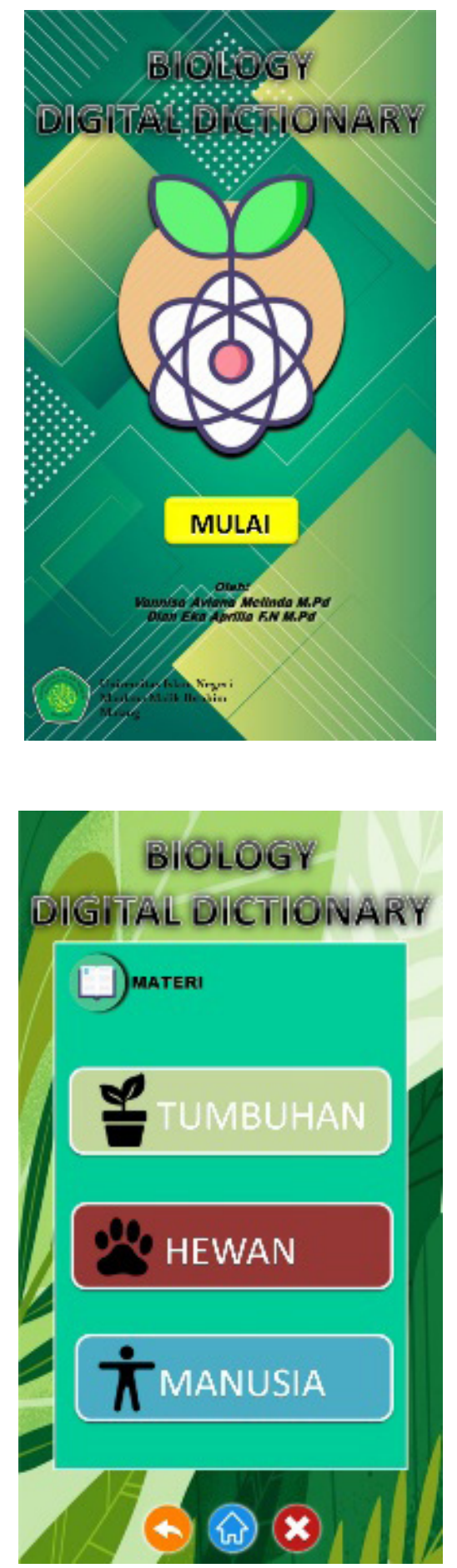

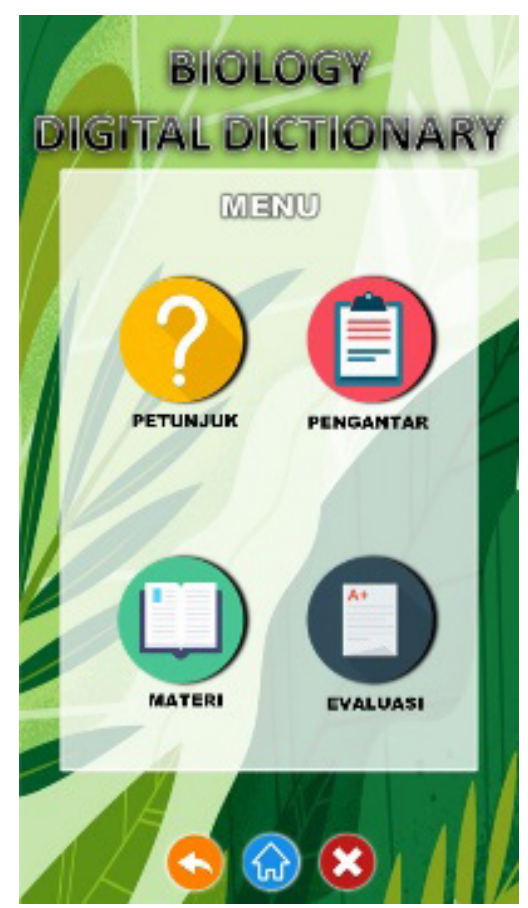

Gambar 2. Digital dictionary

Produk media digital dictionary yang dikembangkan divalidasi oleh ahli materi dan media. Uji validasi dilakukan dengan melibatkan ahli (Akbar, 2016). Ahli adalah seseorang yang berkompeten dalam bidangnya, pada penelitian ini validasi ahli oleh materi dan media. Validasi dilakukan bertujuan untuk menilai kelayakan media digital dictionary sebelum digunakan. Validasi merupakan upaya menghasilkan produk dengan validitas tinggi melalui uji validasi (Akbar, 2016). Hasil validasi mengikuti kriteria kevalidan yang diadaptasi dari Arikunto (2010).

Keseluruhan hasil validasi ahli materi terhadap media digital dictionary yang dikembangkan yaitu 92,30\% dengan kategori valid. Validator memberikan skor 4 pada item "konsep relevan dengan kurikulum, KI, KD". Media digital dictionary yang dikembangkan selaras dengan tujuan pembelajaran yang telah dirumuskan yaitu "mahasiswa mampu menganalisis miskonsepsi yang sering terjadi pada materi tumbuhan, hewan dan manusia. Setiap penulis akan dihadapkan pada tiga pertanyaan yang mendasar ketika akan menulis, yaitu: apa yang akan ditulis, siapayang membacanya, dan bagaimana penulisannya (Trimmer, 2004). Ketiga pertanyaan awal itu dapat dijawab oleh kurikulum (Sitepu, 2015). 
Dengan demikian kurikulum merupakan acuan utama dalam menulis materi pada media pembelajaran.

Validator juga memberikan skor 4 pada item "komponen yang ada sudah memadai sebagai media digital dictionary" $\backslash$ dan pada item "konsep/materi yang tersaji dalam media digital dictionary mampu mempermudah mahasiswa memahami isi materi". Sehingga dapat disimpulkan bahwa media digital dictionary ini dapat menunjang pembelajaran. Pembelajaran efektif dapat berlaku jika pendidik mampu memanfaatkan sumber dan media pembelajaran sesuai tuntutan kurikulumnya (Akbar, 2016).

Hasil validasi ahli media terhadap media digital dictionary yang dikembangkan yaitu $91,67 \%$ dengan kategori valid. Pada komponen kegrafikaan, seperti kejelasan gambar, ketepatan gambar, kesesuaian penggunaan variasi huruf, dan kejelasan tulisan/teks pada media, ahli media telah memberikan skor 3-4 yang tergolong baik. Peranan ilustrasi gambar dalam media pembelajaran yaitu: menimbulkan minat dan motivasi, menarik dan mengarahkan perhatian, membantu peserta didik memahami konsep yang sulit dijelaskan dengan kata-kata, membantu peserta didik yang lambat membaca, dan membantu mengingat lebih lama (Sitepu, 2015).

Secara keseluruhan, hasil validasi media digital dictionary ini valid dan dapat digunakan dalam proses pembelajaran pada mata kuliah Kapita Selekta IPA.

Setiap media pembelajaran selalu memiliki kelebihan dan kekurangan, begitupun dengan media digital dictionary yang memiliki kelebihan, kekurangan dan saran untuk pengembangan lebih lanjut. Beberapa kelebihan media Digital dictionary yaitu praktis, menarik dan mudah digunakan, mahasiswa S1 dikenalkan dengan penggunaan digital dictionary khususnya untuk materi IPA, yang mana pada umumnya kamus diperuntukkan untuk belajar Bahasa, memudahkan mahasiswa mengingat kosa kata ilmiah khususnya pada materi IPA, digital dictionary disajikan dengan ilustrasi gambar berwarna, sehingga dapat membantu mahasiswa dalam memvisualkan kata yang dijabarkan oleh kamus tersebut.

Kekurangan media digital dictionary yaitu media digital dictionary belum diimplementasikan pada mata kuliah lain selain Kapita Selekta, sehingga keefektifannya perlu dikaji lebih lanjut, media digital dictionary hanya bisa digunakan untuk pengguna yang memiliki smartphone dan komputer. Sedangkan untuk saran Pemanfaatan yaitu media digital dictionary dapat digunakan sebagai suplemen dalam pembelajaran untuk mahasiswa Strata 1 pada mata kuliah yang relevan dengan isi kamus, pada khususnya mata kuliah peminatan IPA untuk mahasiswa PGMI, media digital dictionary dapat dijadikan rujukan dalam mempelajari istilah-istilah pada IPA, khususnya Biologi.

Saran diseminasi untuk produk media digital dictionary dikembangkan untuk mahasiswa S1 Pendidikan Guru Madrasah Ibtidaiyah (PGMI) UIN Maulana Malik Ibrahim Malang. Penggunaan media digital dictionary dengan skala lebih luas perlu mengkaji ulang mengenai kesesuaian isi kamus dengan sasaran pengguna. Dan yang terakhir yaitu saran pengembangan lebih lanjut yaitu media digital dictionary perlu ditambahkan katakata lain dalam IPA agar semakin lengkap, sehingga dapat dimanfaatkan dalam skala lebih luas.

Digital dictionary yang dikembangkan digunakan untuk mengukur retensi mahasiswa PGMI pada mata kuliah Kapita Selekta IPA. Materi pada mata kuliah ini mengandung istilah-istilah dalam sains yang terkadang asing bagi mahasiswa. Oleh karena itu, penelitian ini sekaligus mengukur retensi mahasiswa setelah menggunakan digital dictionary dalam proses pembelajaran.

Pada penelitian ini, variabel terikat yang digunakan adalah daya retensi (retention rate) siswa terhadap istilah-istilah biologi yang terkandung dalam materi pokok tumbuhan, hewan dan manusia. Data yang diperoleh dalam penelitian ini akan menganalisis hasil belajar siswa dengan menentukan daya retensi siswa. Diperoleh bahwa rerata retensi mahasiswa dalam kurun waktu 2 minggu masih tergolong B (baik) dengan skor 78,46.

Retensi merupakan proses penyimpanan 
pemahaman baru yang diperoleh setelah menerima informasi, selain itu retensi dapat diartikan kemampuan untuk mengingat materi yang telah dipelajari. Seperti halnya ingatan, retensi juga dapat menentukan hasil yang diperoleh peserta didik dalam proses pembelajaran. Retensi adalah penarikan kembali informasi yang pernah diperoleh sebelumnya (Slameto, 2010). Dalam hal ini Informasi yang diterima dapat disimpan untuk: (1) beberapa saat saja, (2) beberapa waktu, (3) jangka waktu yang tidak terbatas.

Kemampuan retensi menunjukkan adanya hubungan memori jangka pendek dengan jangka panjang yang mengindikasikan proses daya ingat peserta didik terhadap materi yang telah dipelajarinya (Dahar, 1996). Menurut Kapadia (2003) retensi yang baik merupakan kebutuhan setiap peserta didik hasil belajar yang baik, karena hasil belajar peserta didik disekolah diukur berdasarkan penguasaan peserta didik atas materi pelajaran yang prosesnya tidak lepas dari kegiatan mengingat (kemampuan meningkatkan retensi).

Hasil penelitian menunjukkan adanya peningkatan nilai rata-rata skor mahasiswa dari 41,46 (nilai pretest) menjadi 78,46 (nilai posttest). Skor tersebut menunjukkan bahwa dengan menggunakan media digital dictionary kemampuan retensi pengetahuan mahasiswa mengalami peningkatan. Sebagaimana Rusman (2017) menegaskan bahwa kehadiran media sangat membantu peserta didik untuk memahami suatu konsep tertentu yang sulit dijelaskan dengan Bahasa verbal (verbal symbol).

Peningkatan kemampuan retensi terjadi karena banyak peserta didik yang masih mengingat soal yang diberikan dan tidak menutup kemungkinan peserta didik berusaha mencari jawaban yang benar dari sumber lainnya sehingga nilai peserta didik tersebut mengalami peningkatan. Hal tersebut menunjukkan memori peserta didik untuk mengingat materi tumbuhan, hewan, dan manusia sudah berpindah dari memori jangka pendek menjadi memori jangka panjang. Sesuai dengan pernyataan Custers (2010) bahwa adanya retensi pengetahuan merupakan proses terjadinya pemindahan informasi dari memori jangka pendek ke memori jangka panjang.

Fenomena peningkatan retensi ini menarik, mengingat penurunan yang diharapkan dalam tingkat retensi mahasiswa tahun pertama (O'Keeffe, 2013). Maka dari itu, digital dictionary merupakan salah satu alternatif untuk meningkatkan retensi khususnya pada kosa kata biologi.

Penelitian dengan menggunakan metode $R$ \& $D$ untuk mengembangkan kamus telah banyak dilakukan salah satunya oleh Ichsan \& Norhayati (2017) yang membuat kamus biologi berbasis android. Peneliti membahas pengembangan kamus biologi dengan sudut pandang bahasa pemrograman. Penelitian lain mengenai pengembangan kamus berbasis android dilakukan oleh Aryantika et al. (2015) dengan mengembangkan kamus kolok visual berbasis android sebagai media edukatif mempelajari Bahasa penyandang tuna rungu di Desa Bengkala.

Penelitian mengenai pengukuran retensi mahasiswa juga telah banyak dilakukan, salah satunya oleh Simanihuruk et al. (2017) yang meneliti mengenai penerapan pendekatan pembelajaran saintifik pada mata kuliah pendidikan IPA SD kelas tinggi untuk meningkatkan hasil belajar dan retensi mahasiswa PGSD. Hasil penelitian tersebut diperoleh bahwa retensi mahasiswa meningkat setelah menerapkan pendekatan pembelajaran saintifik. Penelitian lain mengenai pengukuran retensi siswa dilakukan oleh Islamiyah et al. (2019) yang bertujuan untuk mengetahui efek dari zentangle terhadap retensi memori. selain itu, Pechenkina et al (2017), juga meneliti tentang peningkatan retensi yang berjudul "Using a gamified mobile app to increase student engagement, retention and academic achievement" dan membuktikan bahwah dengan penggunaan aplikasi mobile dapat meningkatkan retensi siswa sebesar $12,23 \%$.

Berdasarkan penjabaran mengenai kajian terdahulu di atas, maka perbedaan penelitian ini dengan penelitian terdahulu yaitu penggabungan antara metode $R$ \& $D$ untuk mengembangkan kamus digital serta implementasinya untuk mengukur retensi mahasiswa (variabel terikat). 


\section{SIMPULAN}

Berdasarkan hasil penelitian dan pembahasan, kesimpulan dalam penelitian ini yaitu media digital dictionary dapat digunakan sebagai media pembelajaran pada mata kuliah Kapita Selekta IPA untuk mahasiswa S1 PGMI UIN Maulana Malik Ibrahim Malang berdasarkan hasil validasi oleh ahli materi dan ahli media. Media digital dictionary dapat meningkatkan retensi mahasiswa S1 PGMI pada mata kuliah Kapita Selekta IPA.

\section{DAFTAR PUSTAKA}

Akbar,S. (2016). Instrumen Perangkat Pembelajaran. Bandung: Remaja Rosdakarya.

Aryantika, M.E., Darmawiguna, I.G.M. \& Putrama, I.M., (2015). Pengembangan Kamus Kolok Visual Berbasis Android Sebagai Media Edukatif Mempelajari Bahasa Penyandang Tuna Rungu di Desa Bengkala. Jurnal KARMAPATI, 4(4), pp.1-8.

Bishop,G. (2000). Developing learner strategies in the use of dictionaries as a productive language learning tool. The Language Learning Journal, 22,58-62

Custers. A. (2010). Long-term Retention of Basic Science Knowledge: A Review Study. Health Science Education, 15 (1). HIm. 109-128.

Dahar, Ratna Wilis. (1996). Teori-teori Belajar. Jakarta: Erlangga.

Gronlund, N.E\&Linn, R.L.(1990). Measurement and Evaluation in Teaching. New York: McMillan Company.

Hua, Tan Kim dan Peter Charles Woods, (2008). Media-Related Or Generic-Related Features In Electronic Dictionaries: Learners' Perception And Preferences. GEMA Online Journal of Language Studies. 8 (2).

Ichsan, M. \& Norhayati, (2017). Kamus IImu Biologi Berbasis Android. Jurnal Saintekom, 7(1), pp.48-55.

Islamiyah, A. et al., (2019). Pengaruh zentangle pada kemampuan retensi memori. Empati, 8(2), pp.78-89.

Juniarsih, Q.A., L.Chamisijatin, dan I. Hindun. (2015). Peningkatan Retensi Belajar
Materi Klasifikasi Makhluk Hidup Melalui Penerapan Discovery Learning Dan Team Games Tournament Pada Siswa Kelas VII-G SMP Negeri 18 Malang. Prosiding Seminar Nasional Pendidikan Biologi

Kapadia, Mahesh. (2003). Daya Ingat (Bagaimana Mendapatkan yang Terbaik). Jakarta: Pustaka Populer Obor. Laufer, B.(2010). The contribution of dictionary use to the production and retention of collocations in a second language, International Journal of Lexicograhy, 24, 29-49.

Lee, W.W. and Owens D. L.2004. MultimediaBased Instructinal Design, San Francisco, USA : Pfeiffer, an imprint of Wiley.

Nesi, H. (2009). 'Dictionaries in electronic form', in Cowie, A.P. (Ed.), The Oxford History of English Lexicography, Oxford University Press.

Ningsih, S, Adesti, A. (2019). Pengembangan Mobile Learning Berbasis Android pada Mata Kuliah Strategi Pembelajaran Universitas Baturaja. Edcomtech Jurnal Kajian Teknologi Pendidikan 4 (2), 163172

O'Keeffe P. (2013). A sense of belonging: Improving student retention. College Student Journal, 47(4), 605-613.

Pechenkina et al. (2017). "Using a gamified mobile app to increase student engagement, retention and academic achievement". International Journal of Educational Technology in Higher Education, 14:31

Rahman, (2010). Peranan pertanyaan terhadap kekuatan retensi dalam pembelajaran sains pada siswa SMA. Dalam Educare: Jurnal pendidikan dan budaya

Rusman.(2017). Belajar dan Pembelajaran Berorientasi Standar Proses Pendidikan. Jakarta: Prenadamedia Group

Sambung, D., Sihkabuden, S., \& Ulfa, S. (2017). Pengembangan Mobile Learning Berbasis Gamifikasi Untuk Penguasaan Kosakata Bahasa Jepang Kelas X SMAN 1 Garum. Jurnal Inovasi dan Teknologi Pembelajaran, 3(2).

Simanihuruk, L. et al., (2017). Penerapan 
Pendekatan Pembelajaran Saintifik Pada Mata Kuliah Pendidikan IPA SD Kelas Tinggi untuk Meningkatkan Hasil Belajar dan Retensi Mahasiswa PGSD. Handayani, 8(1), pp.94-103.

Sitepu, B. P.(2015). Penulisan Buku Teks Pelajaran. Bandung: PT Remaja Rosdakarya Offset.

Suroso, Amin . (2010). Pengaruh Metode Diskusi Bervariasi Terhadap Prestasi Belajar Pokok Bahasan Sistem Persamaan Linier Dua Variabel Ditinjau Dari Retensi SIswa Kelas II Semester 1 SMP Negeri 6 Surakarta Tahun Pelajaran 2009/2010 .Surakarta: Arsip Skripsi Universitas Sebelas Maret, 34-35.

Slameto, (2010). Belajar \& Faktor-Faktor yang Mempengaruhinya. Jakarta: PT Rineka Cipta
Trilling, B., \& Hood, P. (1999). Learning, technology, and education reform in the Knowledge Age or "We're Wired, Webbed, and Windowed, Now What?" Educational Technology

Tribble, Christopher. (2003). Five Electronic Learners' Dictionaries. ELT Journal Volume 57, Oxford University Press.

Trimmer, J. F. (2004). The New Writing with a Purpose. Boston: Houghton Mifflin.

Ulfa, Saida .(2014.) Mobile Seamless Learning Sebagai Model Pembelajaran Masa Depan. Jurnal Inovasi dan Teknologi Pembelajaran, 1 (1) 